\title{
Effects of eutrophication on bottom habitat and prey resources of demersal fishes
}

\author{
Sean P. Powers ${ }^{1, *}$, Charles H. Peterson ${ }^{2}$, Robert R. Christian ${ }^{3}$, Elizabeth Sullivan ${ }^{2}$, \\ Monica J. Powers ${ }^{2}$, Melanie J. Bishop ${ }^{2}$, Christopher P. Buzzelli ${ }^{2}$
}

\author{
${ }^{1}$ Department of Marine Sciences, University of South Alabama and the Dauphin Island Sea Laboratory, 101 Bienville \\ Boulevard, Dauphin Island, Alabama 36528, USA \\ ${ }^{2}$ University of North Carolina at Chapel Hill, Institute of Marine Sciences, Morehead City, North Carolina 28557, USA \\ ${ }^{3}$ Department of Biology, East Carolina University, Greenville, North Carolina 27858, USA
}

\begin{abstract}
Estuarine benthic habitats serve as essential feeding grounds for demersal finfishes and shellfishes and provide a link between the water column and demersal fisheries in coastal foodwebs. We hypothesize that the cascading linkages of water-column conditions to benthic invertebrates and from benthic invertebrates (as prey) to demersal fishes are a primary mechanism by which waterquality degradation affects sustainable production of demersal fisheries in coastal ecosystems. To evaluate these linkages, we related changes in water quality to changes in bottom-habitat quality for fishes (defined by the availability of prey resources) and assessed how changes in habitat quality affect fish diet. We examined the first link (water-column conditions to benthos) by intensively sampling the benthic community in the Neuse River Estuary, North Carolina, during 2 summers (1997 and 1998) in which depletion of bottom-water oxygen occurred. Dramatic decreases in the abundance of benthic macroinvertebrates were evident after hypoxia/anoxia in both years. Abundances of the clam Macoma balthica, a key prey item for fishes and crabs and the biomass dominant in the benthos, decreased by over $90 \%$ in deep and mid-depth areas ( $>2 \mathrm{~m})$ throughout the estuary after hypoxia/anoxia in 1997. Although summer decreases in benthic macroinvertebrates were also exhibited in 1998, a year of less frequent and less severe hypoxia, the magnitude of decline was less than that of 1997. To evaluate how these changes in prey abundance may affect demersal fishes, we analyzed the diet of Atlantic croaker Micropagonias undulatus, the most abundant demersal fish in the system, prior to and after summer hypoxia of 1998. This analysis demonstrated a shift in croaker diet away from clams, an abundant item before hypoxia, to less nutritional items such as plant and detrital material afterwards. This dietary shift reflects the decreased abundance of clams as a result of hypoxia/anoxia. We conclude from our study of the Neuse River Estuary that hypoxia/anoxia events degrade essential fish habitat and that this degradation has the potential to reduce the capacity of the system to support production of demersal fisheries.
\end{abstract}

KEY WORDS: Benthic invertebrates - Essential fish habitat - Habitat degradation - Hypoxia . Secondary production $\cdot$ Trophic linkages $\cdot$ Neuse River Estuary

\section{INTRODUCTION}

Nutrient enrichment is a pervasive and growing problem for aquatic ecosystems (Rosenberg 1985, Elmgren 1989, Nixon 1995, Jørgensen \& Richardson 1996, Livingston 2001), where increased nutrient loading typically results in elevated rates of phytoplankton production (Richardson \& Heilmann 1995, Paerl et al. 1998, Cloern 2001). In oligotrophic waters, inputs of nutrients and the resultant increased primary productivity typically enhance secondary production (Pearson 1975, Nixon \& Buckley 2002) including that of fishes (Caddy 1993, Maceina \& Bayne 2001). In eutrophic systems, however, which already have high levels of 
primary production, additional nutrients may translate into additional production for pelagic fishes (Breitburg 2002) but not for demersal fishes (Breitburg 2002, Eby \& Crowder 2002). For benthic habitats, much of the increased primary production is delivered directly to microbial loops (Baird et al. 2004). Higher rates of microbial decomposition can deplete dissolved oxygen near the sediment-water interface and produce $\mathrm{H}_{2} \mathrm{~S}$ that enters the water column (Stanley \& Nixon 1992, Diaz \& Rosenberg 1995). The resultant hypoxia or anoxia can persist for long enough to cause mortality of benthic invertebrates under conditions of strong watercolumn stratification or stagnation (Falkowski et al. 1980, Rabalais et al. 1994, Gray et al. 2002). Because benthic invertebrates represent an important and easily accessible prey resource for demersal fishes and crabs, factors influencing macroinvertebrate populations can affect production of demersal fishes (Peterson et al. 2000). We hypothesize that these cascading linkages, from water-column conditions to benthic invertebrates and then from benthic invertebrates (prey) to demersal fishes (predators), can lead to degradation of essential fish habitat and thereby represent a primary mechanism by which eutrophication affects sustainability of demersal fish production in aquatic ecosystems.

Low dissolved oxygen (DO) concentrations (hypoxia, DO $<2.0 \mathrm{mg} \mathrm{l}^{-1}$ or anoxia, DO $=0 \mathrm{mg} \mathrm{l}^{-1}$ ) are a symptom of eutrophication in a growing number of estuarine environments worldwide (Rosenberg 1985, Cooper \& Brush 1991, Diaz \& Rosenberg 1995, Diaz 2001). The direct, short-term effects of hypoxic/anoxic events on benthic macroinvertebrate communities are well-documented; however, the longer-term implications of such events on trophic linkages are not fully understood (Breitburg et al. 1997, Breitburg 2002). Declines in the abundance of benthic macroinvertebrates occur in areas that experience either prolonged (e.g. Josefson \& Widbom 1988, Nordberg et al. 2001) or episodic (e.g. Tenore 1972, Harper et al. 1981, Pearson \& Rosenberg 1992, Rabalais et al. 2001a, Hansen et al. 2002) hypoxia/anoxia. The magnitude of these decreases in benthos is primarily dependent on the duration, spatial extent, and severity of the low-oxygen event (Diaz \& Rosenberg 1995, Rabalais et al. 2001b, Gray et al. 2002). Mobile consumers of benthic macroinvertebrates usually emigrate from areas where dissolved oxygen concentrations reach hypoxic levels (Pihl et al. 1991, Pearson \& Rosenberg 1992, Rabalais et al. 2001a). If low-oxygen conditions are relatively mild, some of these demersal consumers may remain in the vicinity and, over the short term, exploit stunned or moribund benthic prey resources not normally available (Pihl et al. 1992, Pihl 1994, Seitz et al. 2003). As dissolved oxygen concentrations rise, mobile demersal consumers return. But, because recolonization of bottom areas by macroinvertebrates is largely dependent on larval supply (Santos \& Simon 1980, Powers et al. 2001), the recovery of prey resources following an extensive hypoxic/anoxic period requires considerably more time than is necessary for predators to migrate back into the area. Give that recolonization of the benthic community may require months, one critical issue that has yet to be addressed is to what degree and for how long the depletion of prey affects production of demersal fishes and crustaceans after a hypoxic event.

Establishing the linkages between water quality, benthic macroinvertebrate communities and demersal fishes requires that we relate changes in water quality to changes in fish-habitat quality (defined by the availability of appropriate prey resources). We explored this linkage by intensively sampling seasonal changes in water-column DO and in the benthic community in the Neuse River Estuary, North Carolina, over the summer season of hypoxia/anoxia in 2 successive years (1997 and 1998). We then evaluated the consequences of changes in benthic prey abundance on the in situ diet of Atlantic croaker Micropogonias undulatus, the most common demersal fish in the system.

\section{MATERIALS AND METHODS}

Study site. The Neuse River, North Carolina, USA drains a $16000 \mathrm{~km}^{2}$ watershed that is dominated by forestry and row-crop agriculture but has been greatly modified in recent years by growing urbanization, industrialization and animal production (Stow et al. 2001, Cooper et al. 2004). Loading of nitrogen within the river basin has increased by $30 \%$ over recent decades (Stow et al. 2001). Symptoms of declining water quality (e.g. nuisance algal blooms, hypoxia, and fish kills, Paerl et al. 1998), have also increased in frequency over this same time period in the estuary fed by the Neuse River. Hydrologically, the Neuse River Estuary (Fig. 1), which flows into Pamlico Sound, has variable salinity, dependent on changing freshwater and saltwater inputs (Pinckney et al. 1997). Depth is relatively shallow (average $<5 \mathrm{~m}$ ), and mixing is strongly wind-driven, with little lunar influence (Robbins \& Bales 1995). Hypoxia and anoxia are seasonal events in the Neuse River Estuary, usually occurring in deep waters for at least a short period of time each summer from June to September (Lenihan \& Peterson 1998, Paerl et al. 1998, Buzzelli et al. 2002). Persistent areas of bottom-water hypoxia generally encompass the deep and mid-depth areas (>3 m) of the Neuse River Estuary, with the shallower stations experiencing only episodic (lasting 4 to $12 \mathrm{~h}$ ) hypoxic events (Luettich et al. 2001). 
Hydrographic surveys. Hydrographic data were collected from spring 1997 through fall 1998. Sampling was designed to estimate the spatial extent and document the temporal pattern of low-oxygen water masses in the Neuse River Estuary (Luetttich et al. 1999). Hydrographic measurements (temperature, salinity, and dissolved oxygen) were taken weekly at midchannel stations during the spring, summer and fall of 1997 and 1998. More extensive hydrographic surveys of mid-channel and cross-channel stations (transects from one shoreline to the other) were made every $2 \mathrm{wk}$ in the summers of 1997 and 1998 (Luettich et al. 1999, Buzzelli et al. 2002). Continuous hydrographic data were collected at 2 mid-channel stations (T90, T115) where unattended monitoring instruments were placed throughout both years (Fig. 1).

Benthic macroinvertebrates. To assess how low-oxygen events altered the benthic invertebrate prey community on the bottom of the estuary, we sampled benthic macrofauna over a wide expanse of the estuary both before and after the season of hypoxia/anoxia in 1997 and again in 1998. Benthic macrofauna was first sampled on a total of 12 cross-river transects in June 1997 (Fig. 1). We sampled 2 each of shallow $(<3 \mathrm{~m})$, deep ( $>6 \mathrm{~m}$ ), and mid-depth ( 3 to $6 \mathrm{~m}$ ) sites across most transects. A subset of 6 transects (Transects 90, 115, 160, 165, 175, 180: Fig. 1), chosen to cover the whole estuary, was re-sampled in August 1997. All transects were again re-sampled in June 1998, whereas in September 1998 the subset of transects re-sampled was expanded to 8 (the same 6 sampled in the previous August plus Transects 100 and 148: Fig. 1). All benthic samples were collected by SCUBA divers using aluminum cores of $10 \mathrm{~cm}$ diameter and $25 \mathrm{~cm}$ height (sediment-surface area sampled by 1 core $=78.5 \mathrm{~cm}^{2}$ ). We took 10 replicate cores, haphazardly located within a $2 \mathrm{~m}$ radius at each site on each sampling date. Samples were sieved through $0.5 \mathrm{~mm}$ mesh and all material that did not pass through the mesh was preserved in $10 \%$ buffered formalin and stained with Rose Bengal. From the 10 replicate benthic samples at each site, a subset of 5 was randomly selected for analysis. All invertebrates, whole and fragmented, and articulated bivalve shells were picked from the remaining sediment and organic debris. This refined sample was then examined with a dissecting scope (Wild, 6 to $50 \times$ ) and all organisms were identified to the lowest possible taxon.

Fish diet. Atlantic croaker Micropagonias undulatus were collected with 2 min mongoose trawls $(50 \mathrm{~mm}$ mesh with $35 \mathrm{~mm}$ thread bag) at each of 4 sites near Transects 165 and 175 in June and September 1998. The fish were kept on ice in the field and frozen immediately upon return to the laboratory. They were later defrosted and body-index measurements were taken (wet weight, total length and standard length). Stomachs were dissected (anterior of the pyloric sphincter), weighed (wet weight), and preserved in ethanol with Rose Bengal stain. Gut contents were identified to the lowest possible taxonomic level. The numbers (N) of each type of item present in a stomach were recorded, and the percent of total stomach volume (V) made up by each item was estimated. These data were then used to calculate an index of relative importance (IRI) and a modified index (MI) (Hayse 1989): IRI $=(\% \mathrm{~N}+$ $\% \mathrm{~V}) \times \% \mathrm{~F}$ and $\mathrm{MI}=\% \mathrm{~F} \times \% \mathrm{~V}$, where $\mathrm{F}=$ frequency .

Data analyses. Nonmetric multidimensional scaling (nMDS) was performed using PRIMER 5 (PRIMER-E, Plymouth, UK: Warwick \& Clarke 1991) to examine patterns in benthic community structure relating to the depth and position of stations along the longitudinal axis of the estuary (distance downstream from the freshwater end of the estuary) for each of the 4 sampling periods. Depth was chosen as a variable for examination because oxygen depletion in bottom-water co-
Fig. 1. Neuse River Estuary showing hydrographic sampling sites (cross-channel [numbered transects], midchannel and continuous recording stations), benthic coring sites and fish collections

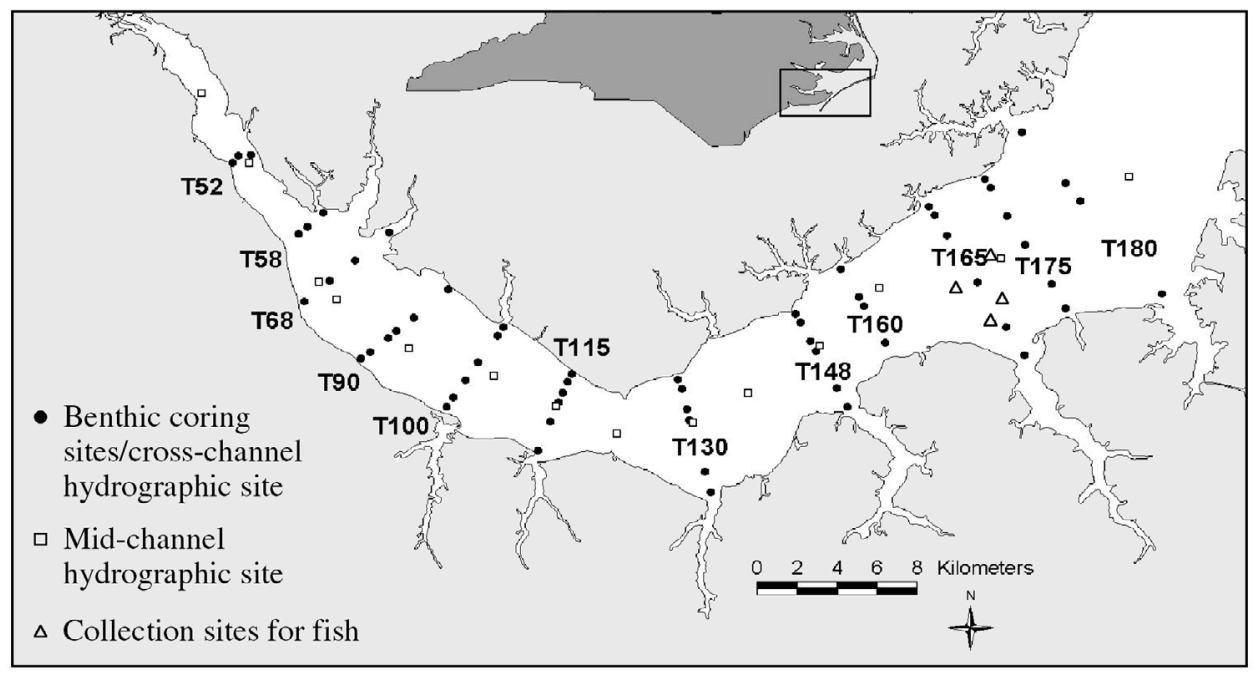


varies with depth such that deep and mid-depth stations experience prolonged episodes of low dissolved oxygen in the summer whereas shallow depths do not. Position along the longitudinal axis of the estuary was chosen because benthic community structure may vary along the salinity gradient of the estuary or with the longitudinal extent of hypoxic bottom-waters. All ordinations were of averages of untransformed data for each station, calculated using the 5 replicates. BrayCurtis measures of dissimilarity were used in construction of the plots. Visual comparisons of plots generated for each collection period were used to characterize differences in community structure by depth and position in the estuary. In addition, the abundances of the 5 dominant taxa were superimposed onto nMDS plots to show their contribution to the multivariate pattern.

To test whether sampling period (June and August 1997, June and September 1998), distance along the longitudinal axis of the estuary (Transects 90, 115, 165, and 175: Fig. 1), depth stratum (shallow $[<3 \mathrm{~m}]$, mid [3 to $6 \mathrm{~m}$ ] and deep [>6 m]), and the interactions of these factors were significant for Macoma balthica or $M$. mitchelli abundances, we performed 3-factor analysis of variance (ANOVA) on transformed $(\log x+1) M$. balthica and $M$. mitchelli abundances. Transformation of the data was necessary after Cochran's C-test detected heterogeneity of variance in the untransformed data. After transformation, Cochran's C-tests confirmed homogeneity of variances at alpha $=0.05$. To resolve the significant 2-factor interactions, we performed Scheffé's post hoc contrasts (Day \& Quinn 1989) within each level of 1 of the factors (depth stratum within each of the 4 sampling periods). For fishdiet analysis, Student's $t$-tests were performed to identify significant changes in MI values of the major diet groups from June to September 1998.

\section{RESULTS}

\section{Hydrographic data}

Salinity and temperature stratification of the water column were common during the summers of 1997 and 1998 (Luettich et al. 1999). Severely hypoxic ( $\left.\leq 2 \mathrm{mg} \mathrm{l}^{-1}\right)$ conditions in bottom waters were detected in the sum-

Table 1. Hypoxia-severity rankings for Neuse River Estuary sampling sites based on twice-weekly hydrographic surveys $(\mathrm{n}=12)$ from June to September 1997. Transects ran from N to $\mathrm{S}$ through shallow ( $<3 \mathrm{~m})$, mid (3 to $6 \mathrm{~m})$ and deep ( $>6 \mathrm{~m})$ waters. Severity rankings were low: only 1 observation with DO levels $\leq 2.0 \mathrm{mg} \mathrm{l}^{-1}$ and no observations $<0.5 \mathrm{mg} \mathrm{l}^{-1}$; moderate: 2 to 3 observations $<2.0 \mathrm{mg} \mathrm{l}^{-1}$, none of these $<0.5 \mathrm{mg} \mathrm{l}^{-1}$; high: $\geq 4$ observations $<2.0 \mathrm{mg} \mathrm{l}^{-1}$ or $\geq 1$ observations $<0.5 \mathrm{mg} \mathrm{l}^{-1}$

\begin{tabular}{|c|c|c|c|c|c|c|c|}
\hline \multirow[t]{2}{*}{ Transect } & \multirow[t]{2}{*}{ Depth } & \multicolumn{2}{|c|}{$\mathrm{DO}<2 \mathrm{mg} \mathrm{l}^{-1}$} & \multicolumn{2}{|c|}{$\mathrm{DO}<0.5 \mathrm{mg} \mathrm{l}^{-1}$} & \multicolumn{2}{|c|}{ Hypoxia severity } \\
\hline & & 1997 & 1998 & 1997 & 1998 & 1997 & 1998 \\
\hline \multirow[t]{6}{*}{90} & Shallow (north shore) & 0 & 1 & 0 & 0 & Low & Low \\
\hline & Mid & 3 & 2 & 0 & 0 & Moderate & Moderate \\
\hline & Deep & 6 & 5 & 2 & 2 & High & High \\
\hline & Deep & 6 & 5 & 1 & 2 & High & High \\
\hline & Mid & 3 & 2 & 1 & 0 & High & Moderate \\
\hline & Shallow (south shore) & 0 & 1 & 0 & 0 & Low & Low \\
\hline \multirow[t]{6}{*}{115} & Shallow (north shore) & 0 & 0 & 0 & 0 & Low & Low \\
\hline & Mid & 2 & 3 & 0 & 0 & Moderate & Moderate \\
\hline & Deep & 4 & 5 & 1 & 0 & High & High \\
\hline & Deep & 4 & 5 & 1 & 0 & High & High \\
\hline & Mid & 2 & 2 & 0 & 0 & Moderate & Moderate \\
\hline & Shallow (south shore) & 0 & 0 & 0 & 0 & Low & Low \\
\hline \multirow[t]{6}{*}{165} & Shallow (north shore) & 0 & 0 & 0 & 0 & Low & Low \\
\hline & Mid & 1 & 0 & 0 & 0 & Low & Low \\
\hline & Deep & 3 & 0 & 3 & 0 & High & Low \\
\hline & Deep & 2 & 1 & 2 & 1 & High & High \\
\hline & Mid & 1 & 0 & 0 & 0 & Low & Low \\
\hline & Shallow (south shore) & 1 & 0 & 0 & 0 & Low & Low \\
\hline \multirow[t]{6}{*}{175} & Shallow (north shore) & 1 & 1 & 0 & 0 & Low & Low \\
\hline & Mid & 2 & 1 & 2 & 0 & High & Low \\
\hline & Deep & 3 & 1 & 3 & 0 & High & Low \\
\hline & Deep & 2 & 1 & 2 & 0 & High & Low \\
\hline & Mid & 2 & 0 & 0 & 0 & Moderate & Low \\
\hline & Shallow (south shore) & 1 & 0 & 0 & 0 & Low & Low \\
\hline \multirow[t]{3}{*}{ Total } & Shallow & 3 & 3 & 0 & 0 & Low & Low \\
\hline & Mid & 16 & 11 & 3 & 0 & Moderate-high & Low-moderate \\
\hline & Deep & 30 & 23 & 15 & 5 & High & Moderate-high \\
\hline
\end{tabular}


mers of 1997 and 1998 during periods of water-column stratification. The mid-channel depth of the oxycline, the zone between oxygenated surface waters and severely hypoxic bottom-waters averaged 1.0 to $1.5 \mathrm{~m}$ above the bottom at deep sites during hypoxic periods. In the hydrographic data, 2 patterns were evident for low dissolved oxygen: (1) oxygen depletion (hypoxia or anoxia) was more severe at deeper depths (Table 1); (2) the frequency of occurrence and average and seasonal maximum spatial extent of bottom water hypoxia were greater in 1997 than 1998 (Table 2). In summer 1997, the most persistent event of severe hypoxia occurred in bottom waters in July and early August of 1997, with a brief return to oxygenated conditions at deep sites before short-term hypoxia occurred again in early September of 1997 (Luettich et al. 1999). Deep sites on Transects 90, 115, 165, 175 experienced almost continuous (inferred from our weekly mid-channel surveys) exposure to severely hypoxic condition for the entire month of July 1997.

Table 2. Spatial extent of hypoxic (dissolved oxygen $<2 \mathrm{mg} \mathrm{l}^{-1}$ ) bottom water in Neuse River Estuary during summers of 1997 and 1998 based on weekly mid-river hydrographic sampling. $\%$ upstream, \% downstream: percent of total hypoxic bottom area above Transect 120 (upstream) or below Transect 120 (downstream)

\begin{tabular}{|lccc|}
\hline $\begin{array}{l}\text { Sampling } \\
\text { date }\end{array}$ & $\begin{array}{c}\text { Total hypoxic } \\
\text { bottom area }\left(\mathrm{km}^{2}\right)\end{array}$ & $\begin{array}{c}\% \\
\text { upstream }\end{array}$ & $\begin{array}{c}\% \\
\text { downstream }\end{array}$ \\
\hline 1997 & & & \\
10 Jun & 0 & & \\
24 Jun & 81 & 57 & 43 \\
1 Jul & 9 & 100 & 0 \\
8 Jul & 70 & 59 & 41 \\
15 Jul & 14 & 95 & 5 \\
21 Jul & 117 & 75 & 25 \\
29 Jul & 75 & 74 & 26 \\
4 Aug & 16 & 100 & 0 \\
12 Aug & 12 & 100 & 0 \\
20 Aug & 53 & 82 & 18 \\
27 Aug & 14 & 100 & 0 \\
17 Sep & 68 & 55 & 45 \\
Average & 44 & 81 & 19 \\
1998 & & & \\
2 Jun & 85 & 30 & 70 \\
8 Jun & 0 & & \\
15 Jun & 0 & & \\
30 Jun & 0 & & \\
6 Jul & 0 & & \\
13 Jul & 0 & & \\
21 Jul & 45 & 64 & 100 \\
30 Jul & 68 & & \\
4 Aug & 0 & & \\
10 Aug & 69 & & \\
17 Aug & 50 & & \\
25 Aug & 18 & & \\
9 Sep & 0 & & \\
Average & 26 & & \\
\hline
\end{tabular}

In summer 1998, hypoxic conditions were not detected in deep mid-river sites on Transects 165 and 175 after late July or downstream of Transect 90 after late August. Deep and middle-depth sites on or upstream of Transect 115 experienced 2 periods when hypoxic conditions were detected on at least 2 consecutive sampling dates: on May 27 and June 2, 1998, hypoxic conditions were recorded at deep and mid-depth sites on or upstream of Transect 115. On June 6, 1998 hypoxic conditions were not recorded anywhere on these transects. The second period of sustained hypoxia was first detected on July 21, then again on July 30, but ended before August 4, 1998. For Transects 165 and 175 , there were no hypoxic events that persisted for 2 consecutive weekly measurements in 1998.

The area of seafloor habitat covered by hypoxic bottom-water averaged $44 \mathrm{~km}^{2}$ (range $=0$ to $117 \mathrm{~km}^{2}$ ) in the summer of 1997 and $26 \mathrm{~km}^{2}$ (range $=0$ to $85 \mathrm{~km}^{2}$ ) in the summer of 1998 (Table 2). For the period June 10 to September 2, 1997, only 1 (June 10) of a total of 10 sampling dates displayed no hypoxic bottom water. From June 2 to September 9, 1998, 7 out of 13 surveys revealed no hypoxia anywhere in the estuary (Table 2). During both years the majority ( $>78 \%$ ) of the hypoxic area was upstream of Transect 120 (Table 2), although this upstream region comprises only half the areal extent of the downstream region. Differences in the frequency of occurrence of hypoxic conditions between 1997 and 1998 were for the most part evident in the area downstream of Transect 120 not in the upstream section (Table 1).

\section{Benthic macroinvertebrates}

Analysis of cores revealed an infaunal community typical of southeastern US and mid-Atlantic mesohaline estuaries (see Tenore 1972). By biomass, Macoma balthica and $M$. mitchelli accounted for the majority (80 to $90 \%$ ) of the infaunal community of the Neuse River Estuary prior to hypoxic conditions. Spionid and capitellid polychaetes accounted for the majority of the remaining infaunal biomass. The bivalves Mulinia lateralis and Rangia cuneata were also present near the upper reaches of the estuary. Amphipods and chironomid larvae (insects) were common in many samples, although they accounted for a small proportion of total biomass. Prior to hypoxic conditions in June 1997 , nMDS plots showed relatively little separation among stations by depth (Fig. 2). Following the summer of intense hypoxia at deep and some mid-depth stations, separation of shallow and deep stations by depth was evident (Fig. 2). This depth pattern persisted for both sampling dates in 1998. Superimposing the abundances of individual taxa onto the nMDS plots to show 

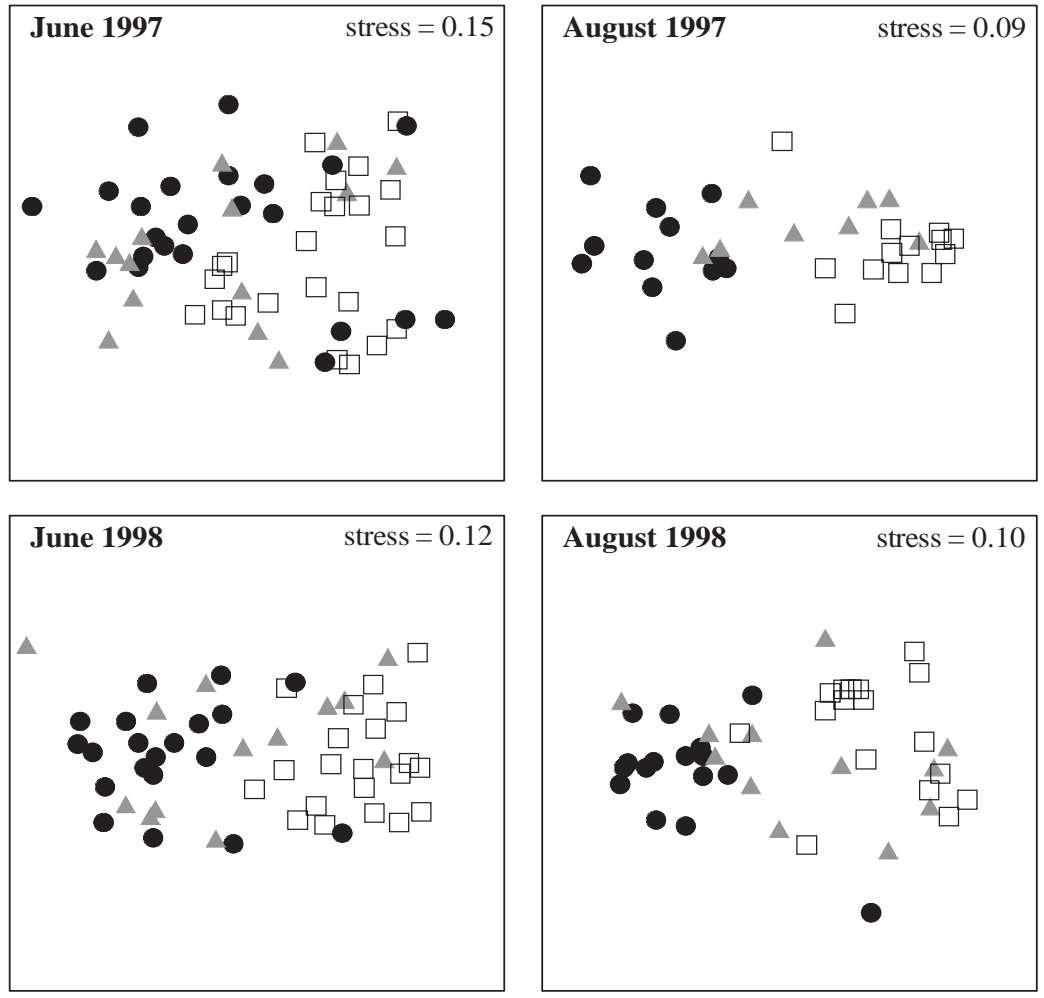


and deep ( $\square$ ) depths of Neuse River in June and August 1997 and June and August 1998. Data points represent averages of untransformed data from each site $(n=5)$. Stress indicates degree to which plot represents data (stresses of $<0.15$ are considered good representations, with minimal risk of misinterpretation)

and M. mitchelli abundances were essentially zero at all deep sites, and significantly lower than at the shallow depth $(\mathrm{p}<0.05$ for both $M$. balthica and $M$. mitchelli). Abundances of $M$. mitchelli also differed with depth in September 1998: shallow depths had higher abundances than deep and mid-depth areas $(p<0.05$ for both comparisons), which did not differ $(\mathrm{p}>$ 0.05). M. balthica displayed an identical pattern of changing abundance with depth in September 1998, but no difference was significant. Consequently, both species of Macoma displayed an absence of detectable depth relationships in early summer before the season of oxygen depletion, followed by evolution of a pattern over the course of summer such that deep areas became relatively depleted. This seasonal response was quantitatively stronger in 1997 and even extended the detectable depletion to mid-depths for M. mitchelli in summer 1997 (Fig. 4).

Analysis of the interaction of transect location and depth revealed greater depletion of both species of Macoma at mid-depth sites on up-river transects (90 and 115) than down-river transects (165 and 175). For M. balthica and $M$.

their contribution to the multivariate pattern among depths, revealed that $M$. balthica, M. mitchelli and spionid polychaetes each responded in a similar manner to station depth, with highest densities at shallow depths (Fig. 3).

Results of ANOVAs testing whether the abundances of Macoma balthica or M. mitchelli varied with sampling date, transect location and depth stratum, were consistent with the emergence and persistence of the depth pattern evident in the nMDS plots. For each species, ANOVA showed all 2-way interactions among combinations of sampling period, depth stratum, and transect location to be significant ( $p<0.05$ ) or marginally significant $(0.05<\mathrm{p}<0.10)$. The 3 -way interaction was not significant for either Macoma species. To resolve the 'sampling period $\times$ depth' interaction, we examined how abundance varied with depth within each sampling period. Abundance of $M$. balthica differed with depth only for the August 1997 sampling period (Fig. 4). M. mitchelli abundances differed with depth in both post-hypoxia samplings (August 1997, September 1998), but did not differ in either of the June sampling periods. In August 1997, M. balthica mitchelli, deep and mid-depth sites had lower abundances than shallow sites ( $\mathrm{p}<0.05$ for all post hoc contrasts) on Transects 90 and 115, whereas mid-depth sites showed higher abundances than deep sites ( $\mathrm{p}<$ 0.05 for post hoc contrasts) and did not differ from shallow sites ( $p>0.05$ for post hoc contrasts) on Transects 165 and 175.

\section{Fish diets}

Gut-content analysis of Micropogonias undulatus revealed that food types shifted in importance between June and September 1998 at the 4 sites (all > $5 \mathrm{~m}$ deep: see Fig. 1) that were sampled both before and after hypoxia. Although a wide range of items was found in the fish stomachs, both the IRI and MI values show that gut contents predominately consisted of 4 different items: shell, tissue, polychaetes and plant matter ('tissue' is unidentifiable animal tissue that has been digested to an extent that prohibits confident visual differentiation). These 4 items all had MI values approaching or above 1000 for at least 1 of the 2 dates, 

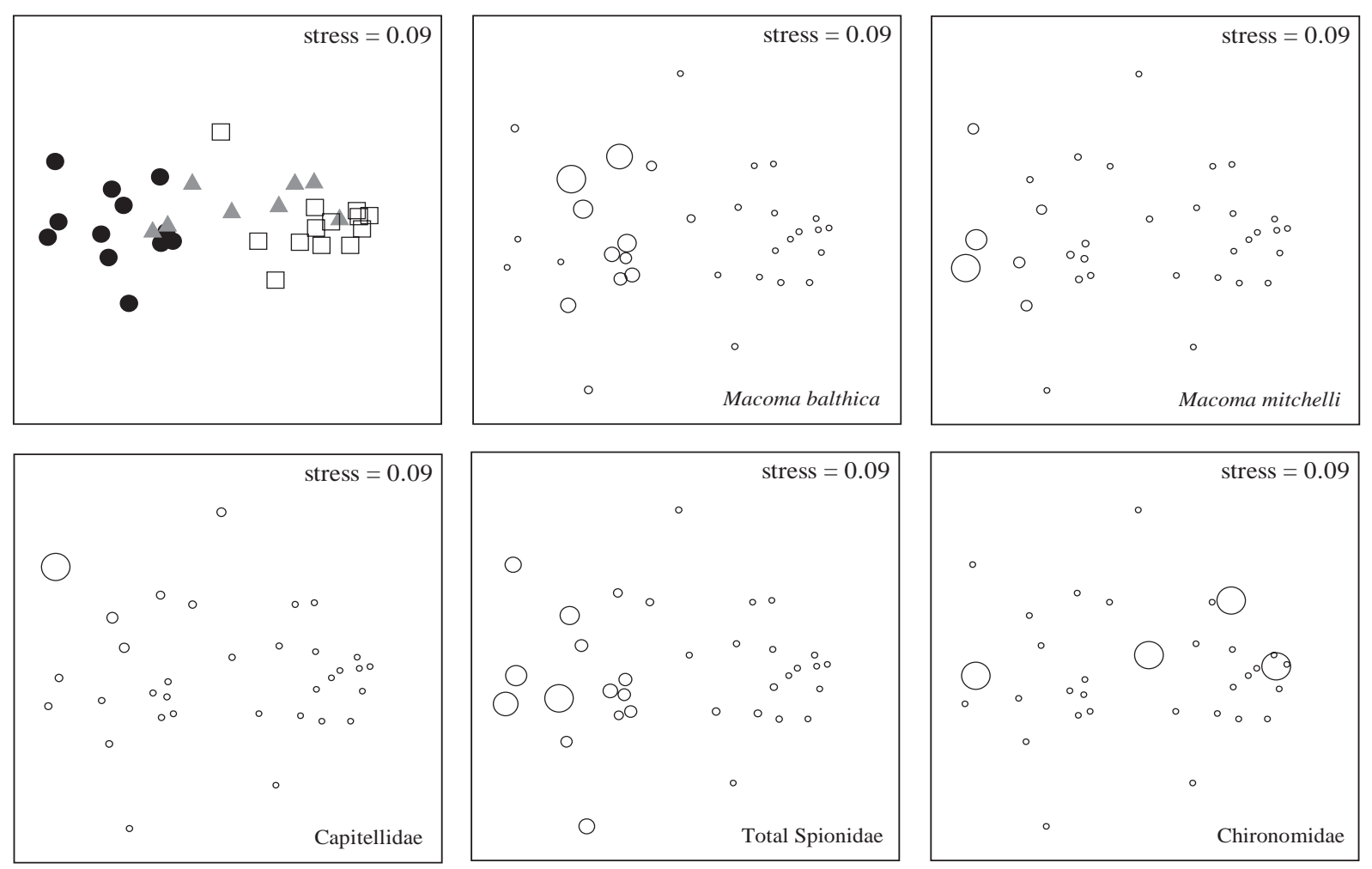

Fig. 3. nMDS ordination of assemblages of macrofauna found at shallow (•), mid ( $\mathbf{\Delta}$ ) and deep ( $\square$ ) depths of the Neuse River and relative abundances (represented by size of data points) of Macoma balthica, M. mitchelli, Capitellidae, Spionidae and Chironomidae in August 1997. Data points represent averages of untransformed data from each site $(n=5)$ and stress indicates degree to which plot represents data. Abundance patterns of $M$. balthica, $M$. mitchelli and Spionidae are highly representative of overall multivariate pattern. Similar findings were evident for the 3 other collection periods

while the other food items rarely reached a MI of 500 . Analysis of the croaker diets (MI) from the 4 sites indicated that the importance of shell (indicative of feeding on Macoma spp. based upon our examination of gut contents from experimental assays) decreased between June and September $(p=0.02)$ while the importance of polychaetes and plants increased $(\mathrm{p}<0.02)$. These data indicate that the fish were preying on fewer (or smaller) bivalves after hypoxia, and that they were instead relying more on polychaete and plant material (Fig. 5).

\section{DISCUSSION}

Declines in dissolved oxygen that result in large part from eutrophication (Diaz \& Rosenberg 1995, Jørgensen \& Richardson 1996, Gray et al. 2002) degrade the estuarine bottom habitat essential for rearing of demersal fishes and crustaceans. Significant changes in the quality of bottom habitat occurred over the course of the summer in the Neuse River Estuary. Although an array of physical and biological factors is known to affect benthic community composition, the data reported here provide strong evidence that the stress of low oxygen caused substantial impacts on macrofaunal community composition between June and September 1997 in the deep and mid-depth habitats of the Neuse River Estuary. Furthermore, our comparison between years in seasonal changes in the benthic community supports the conclusion that the degree of habitat degradation reflects the severity of summer hypoxia. Finally, the fish diet analyses support our contention that hypoxia-induced changes in benthic habitat can be transmitted up the food chain to demersal fishes.

In order to conclude that hypoxia was the most likely cause of the observed changes in benthic communities between June and August 1997, dissolved oxygen concentrations over that time period must have been sufficient to cause infaunal mortality. The dissolved oxygen dynamics at all deep sites on all transects included at least 1 to $2 \mathrm{wk}$ under $0.5 \mathrm{mgDO} \mathrm{l}^{-1}$ (Tables 1 \& 2), a concentration known to cause mass mortality of benthic infauna (see Diaz \& Rosenberg 1995 for review). Resolution of DO data does not allow more precise temporal estimates, but these events were of sufficient 

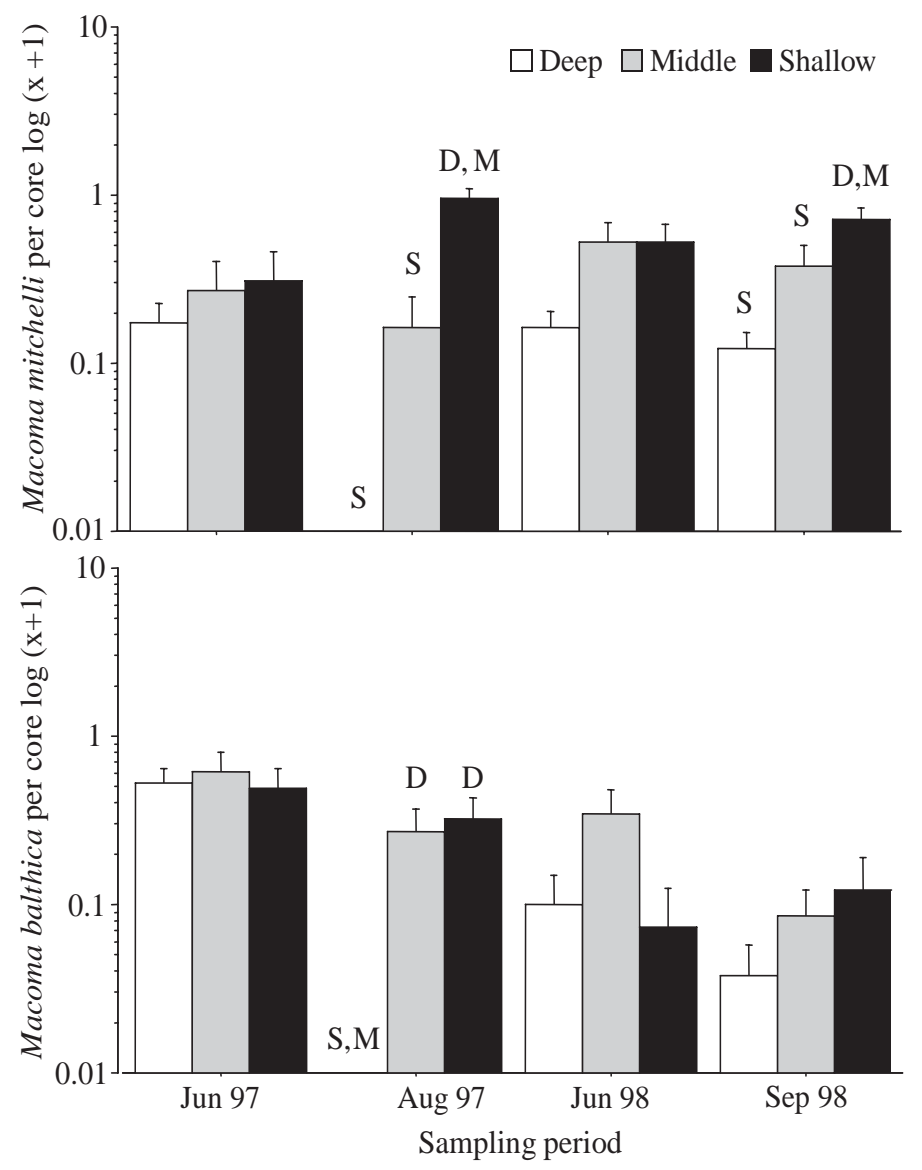

Fig. 4. Macoma mitchelli and M. balthica. Mean abundance $(+1 \mathrm{SE})$ of $76.3 \mathrm{~cm}^{-2}$ core within in each depth stratum for the 4 sampling periods. Data were $\log (x+1)$-transformed. Letters above bars denote significant post hoc differences $(p<0.05)$, where $\mathrm{S}=$ mean values differed from shallow sites, $\mathrm{M}=$ mean values differed from mid-depth sites, $\mathrm{D}=$ mean values differed from deep sites within the relevant sampling period intensity to have caused the mortality observed in Macoma balthica (Modig \& Ólafsson 2001, Borsuk et al. 2002). The weaker response of the benthic community to the less intense hypoxia of summer 1998 also supports the conclusion that the stress of persistent low DO was indeed the cause of the declines in Macoma spp. in summer 1997.

The dominant patterns of change in the benthic infaunal community between June and August 1997 agree with our predictions of community responses to seasonal hypoxic disturbance. Shallow sites exhibited declines in Macoma spp. abundances, but they did not exhibit defaunation to the same degree as all the deep sites. Macoma spp. is a very important food species for the dominant demersal consumers in this system, blue crabs (Hines et al. 1990, Seitz et al. 2003), spot (which consume primarily clam siphons: Hines et al. 1990, Skilleter \& Peterson 1994), and Atlantic croaker (Eby et al. 2005, this study). By September 1997, mortality of adult $M$. balthica at deep sites was $100 \%$, and recruitment was extremely low (only 2 individuals pooled over all sites), while in middle and shallow sites both adult and juvenile clams were present. This corresponds with observations by Holland et al. (1987), who noted that more than 1 yr-class of $M$. balthica was rarely found at deep sites in the Chesapeake Bay, which experiences seasonal anoxia.

The pattern of smaller declines in benthic infaunal densities at shallower sites is not consistent with an alternative explanation that predation may have been the cause of the summer decline. Although predation by demersal consumers on Macoma spp. can contribute to declining prey populations, the spatial and temporal patterns of summertime depletion of Macoma spp. that we documented are inconsistent with predation. Under normoxic conditions, demersal predators feed in both shallow and deep waters of the Neuse River Estuary with bias against deep-water locations (Lenihan et al. 2001), whereas the seasonal imposition of hypoxia in deeper waters actually drives demersal predators into shallow areas and enhances their feeding in shallow, not deep, zones (Lenihan et al. 2001, Eby et al. 2005). Consequently, depth-related patterns produced by predators would exhibit a pattern opposite to that observed, namely greater summertime declines in benthic macroinvertebrate densities in shallow sites. Similarly, the interannual difference in the magnitude of summertime decline in macrobenthic densities cannot be explained by differences in predator abundance between 1997 and
Fig. 5. Micropogonias undulatus. Mean (+1 SE) values of modified index of importance (MI) for 4 diet groupings for Atlantic croaker before and after hypoxia. Statistical significance based on Student's $t$-test results for June 1998 versus September 1998 fish collections 
1998: the abundances of both spot and croaker, the dominant demersal consumers, were at least 2 times higher in 1998 than in 1997 (Baird et al. 2004).

Our 4 samplings of benthic invertebrate densities provide some insight into the recovery of the benthic community during the fall, winter and spring following severe hypoxia in summer 1997. Macoma balthica at deep sites had not regained their June 1997 abundance levels by the following June. Based upon a detailed analysis of Macoma spp. collections made in both June and August of 1968, 1969, 1970, and 1971 (years that also experienced severe summer hypoxia), the failed recovery that we report in this study is not representative of most years (H. Porter unpubl. data). A likely explanation for the recovery failure from late summer 1997 to June 1998 is that unusually intense spring rainfall over the Neuse River basin (Luettich et al. 1999) inhibited successful recovery of benthic invertebrates. Luetttich et al. (1999) showed that a large portion of the estuary had uncharacteristically low salinities $(<2)$ from March through April as a result of the high freshwater inputs. This interpretation gains support from the observation that $M$. mitchelli, the more estuarine species, showed full recovery, while $M$. balthica, the more stenohaline species, failed to recover its June 1997 density.

Establishing the final, cascading linkage, the impact of degraded bottom habitat on demersal fishes, depends on assessing how declines in benthic prey resources affect demersal predators. Our analysis of gut contents of croaker in the Neuse River Estuary demonstrates a shift in the importance of different dietary items over the course of summer 1998 (Fig. 5). Croaker modified their diets from a large amounts of bivalves (denoted by 'shell') in June to dominance by polychaetes and plant material in September. Croaker are known as opportunistic feeders that modify their diet depending on prey availability (Currin et al. 1984, Hines et al. 1990). Thus, the switch from bivalve prey in June to polychaetes and plant matter in September reflects the large summertime decline in Macoma spp. densities in deep and mid-depth areas of the estuary, consistent with the loss of an important and perhaps preferred prey type.

The results of 2 collaborative studies (Baird et al. 2004, Eby et al. 2005) indicate that the summertime declines in availability of benthic invertebrate prey have serious population consequences for demersal fishes as well as impacts on ecosystem processes. Eby et al. (2005) demonstrated that the physiological condition, individual growth rate and population growth of croaker and spot in the Neuse River Estuary were lower in the year of severe hypoxia (1997) than in 2 yr of less intense summertime oxygen depletion (1998, 1999). Combining these results with ours implies that switching from bivalves to alternative prey resources including plant matter did not suffice to sustain high production of demersal fishes throughout the Neuse River Estuary. This conclusion is also supported by the results of trophic mass-balance modeling by Baird et al. (2004), who demonstrated that production of the benthic infauna in the Neuse River Estuary was sufficient to support energy demands by demersal fishes and blue crabs before but not after the large-scale hypoxic event in July 1997.

Modification of benthic communities has the potential to affect a wide range of important processes in an estuarine system. Of primary interest to humans is fisheries production, which is 1 issue addressed in our study of the Neuse River Estuary. Seasonal hypoxia has resulted in the reduction of lobster catches in the Kattegat (Rosenberg \& Loo 1988, Rosenberg et al. 1992), and other extensive hypoxic/anoxic events are responsible for reducing commercial catches of finfishes and crustaceans, both by starvation after loss of the benthic prey community and by direct stress from depleted oxygen (Diaz \& Rosenberg 1995). Hypoxiadriven changes in fishery production are not necessarily all negative. When high biomass of opportunists becomes established after hypoxia, then some demersal feeders may benefit as a result of the enhanced prey. For example, shrimps and other demersal consumers of meiofaunal and small macrofaunal invertebrates may experience higher densities of prey following summer hypoxic events because of colonization by numerous small opportunists (Alongi 1985, Pihl 1994, Diaz \& Rosenberg 1995, Peterson et al. 2000). Further studies connecting hypoxia to tangible changes in fish habitat and ultimately productivity of fisheries, either positive or negative, are needed given the complex nature of coastal foodwebs and the increase in eutrophication-induced hypoxia events around the world.

Acknowledgements. We thank numerous people for help with field and laboratory analyses for this project, especially P. Brown, J. H. Grabowski, H. S. Lenihan, L. M. Manning, J. O'Neal, G. Safrit, S. Saville, and H. Summerson. This research was supported by a grant the North Carolina Water Resources Research Institute with additional support from the North Carolina Fisheries Resource Grant Program, the Environmental Defense Fund and the PEW Charitable Trusts. This is DISL contribution 371

\section{LITERATURE CITED}

Alongi DM (1985) Effect of physical disturbance on population dynamics and trophic interactions among microbes and meiofauna. J Mar Res 43:351-364

Baird D, Christian RR, Peterson CH, Johnson GA (2004) Consequences of hypoxia on estuarine food web and ecosys- 
tem function: energy diversion from consumers to microbes. Ecol Appl 14:805-822

Borsuk ME, Powers SP, Peterson CH (2002) A survival-based assessment of the effects of bottom-water hypoxia on the population density of an estuarine clam (Macoma balthica). Can J Fish Aquat Sci 59:1266-1274

Breitburg DL (2002) Effects of hypoxia, and the balance between hypoxia and enrichment, on coastal fishes and fisheries. Estuaries 25:767-781

Breitburg DL, Loher T, Pacey CA, Gerstein A (1997) Varying effects of low dissolved oxygen on trophic interactions in an estuarine food web. Ecol Monogr 67:489-507

Buzzelli CP, Luettich RA, Powers SP, Peterson CH, McNinch JE, Pinckney JL, Paerl HW (2002) Estimating the spatial extent of bottom-water hypoxia and habitat degradation in a shallow estuary. Mar Ecol Prog Ser 230:103-112

Caddy JF (1993) Toward a comparative evaluation of human impacts on fishery ecosystems of enclosed and semienclosed seas. Rev Fish Sci 1:57-95

Cloern JE (2001) Our evolving conceptual model of the coastal eutrophication problem. Mar Ecol Prog Ser 210: 223-253

Cooper SR, Brush GS (1991) Long-term history of Chesapeake Bay anoxia. Science 254:992-996

Cooper SR, McGlothlin SK, Madritch M, Jones DL (2004) Paleoecological evidence of human impacts on the Neuse and Pamlico Estuaries of North Carolina, USA. Estuaries 27:617-633

Currin BM, Reed JP, Miller JM (1984) Growth, production, food consumption, and mortality of juvenile spot and croaker: a comparison of tidal and nontidal nursery areas. Estuaries 7:451-459

Day RW, Quinn GP (1989) Comparisons of treatments after an analysis of variance in ecology. Ecol Monogr 59:433-463

Diaz RJ (2001) Overview of hypoxia around the world. J Environ Qual 30:275-281

Diaz RJ, Rosenberg R (1995) Marine benthic hypoxia: a review of its ecological effects and the behavioural responses of benthic macrofauna. Oceanogr Mar Biol Annu Rev 33:245-303

Eby LA, Crowder LB (2002) Hypoxia-based habitat compression in the Neuse River Estuary: context-dependent shifts in behavioral avoidance thresholds. Can J Fish Aquat Sci 59:952-965

Eby LA, Crowder LB, McClellan CB, Powers MJ, Peterson CH (2005) Habitat degradation from intermittent hypoxia: impacts on juvenile fishes. Mar Ecol Prog Ser 291:249-262

Elmgren R (1989) Man's impact on the ecosystem of the Baltic Sea: energy flows today and at the turn of the century. Ambio 18:326-332

Falkowski PG, Hopkins TS, Walsh JJ (1980) An analysis of factors affecting oxygen depletion in the New York Bight. J Mar Res 38:479-506

Gray JS, Wu RSS, Or YY (2002) Effects of hypoxia and organic enrichment on the coastal marine environment. Mar Ecol Prog Ser 238:249-279

Hansen BW, Stenalt E, Petersen JK, Ellegaard C (2002) Invertebrate re-colonisation in Mariager Fjord (Denmark) after severe hypoxia. I. Zooplankton and settlement. Ophelia 56:197-213

Harper DE Jr, McKinney LD, Salzer RR, Case RJ (1981) The occurrence of hypoxic bottom water off the upper Texas coast and its effects on the benthic biota. Contrib Mar Sci $24: 53-79$

Hayse JW (1989) Feeding habits, age, growth, and reproduction of Atlantic spadefish Chaetodipterus faber in South Carolina. Fish Bull US Dep Comm 88:67-83
Hines AH, Haddon AM, Wiechert LA (1990) Guild structure and foraging impact of blue crabs and epibenthic fish in a subestuary of Chesapeake Bay. Mar Ecol Prog Ser 67: $105-126$

Holland AF, Shaughnessy AT, Hiegel MT (1987) Long-term variation in mesohaline Chesapeake Bay macrobenthos: spatial and temporal patterns. Estuaries 10:227-245

Jørgensen BB, Richardson K (eds) (1996) Eutrophication in coastal marine ecosystems. American Geophysical Union, Washington, DC

Josefson AB, Widbom B (1988) Differential response of benthic macrofauna and meiofauna to hypoxia in the Gullmar Fjord basin. Mar Biol 100:31-40

Lenihan HS, Peterson CH (1998) How habitat degradation through fishery disturbance enhances impacts of bottom water hypoxia on oyster reefs. Ecol Appl 8:128-140

Lenihan HS, Peterson CH, Byers JE, Grabowski JH, Thayer GW, Colby D (2001) Cascading of habitat degradation: oyster reefs invaded by refugee fishes escaping stress. Ecol Appl 11:746-782

Livingston RJ (2001) Eutrophication processes in coastal systems: origin and succession of plankton blooms and effects on secondary production in Gulf Coast estuaries. CRC Press, New York

Luettich R, Albert D, Alperin M, Bowen J and 16 others (1999) Neuse modeling and monitoring (ModMon), final report. Water Resources Research Institute, Raleigh, NC

Luettich RA Jr, Carr SD, Reynolds-Fleming JV, Fulcher CW, McNinch JE (2001) Semi-diurnal seiching in a shallow, micro-tidal lagoonal estuary. Cont Shelf Res 22:1669-1681

Maceina MJ, Bayne DR (2001) Changes in the black bass community and fishery with oligotrophication in the West Point Reservoir, Georgia. N Am J Fish Manag 21: $1144-1157$

Modig H, Ólafsson E (1998) Responses of Baltic benthic invertebrates to hypoxic events. J Exp Mar Biol Ecol 229: $133-148$

Nixon SW (1995) Coastal marine eutrophication: a definition, social causes, and future concerns. Ophelia 41:199-219

Nixon SW, Buckley BA (2002) 'A strikingly rich zone' - nutrient enrichment and secondary production in coastal marine ecosystems. Estuaries 25:782-796

Nordberg K, Filipsson HL, Gustafsson M, Harland R, Roos P (2001) Climate, hydrographic variations and marine benthic hypoxia in Koljo Fjord, Sweden. J Sea Res 46:187-200

Paerl HW, Pinckney JL, Fear JM, Peierls BL (1998) Ecosystem responses to internal and watershed organic matter loading: consequences for hypoxia in the eutrophying Neuse River Estuary, North Carolina, USA. Mar Ecol Prog Ser 166:17-25

Pearson TH (1975) The benthic ecology of Loch Linnhe and Loch Eil, a sea loch system on the west coast of Scotland. IV. Changes in the benthic fauna attributable to organic enrichment. J Exp Mar Biol Ecol 20:1-41

Pearson TH, Rosenberg R (1992) Energy-flow through the Kattegat: a comparative-examination of the eutrophication of a coastal marine ecosystem. Neth J Sea Res 28: $317-348$

Peterson $\mathrm{CH}$, Summerson $\mathrm{CH}$, Thomson E, Lenihan HS, Grabowski JH, Manning L, Micheli F, Johnson G (2000) Synthesis of linkages between benthic and fish communities as a key to protecting essential fish habitat. Bull Mar Sci 66:759-744

Pihl L (1994) Changes in the diet of demersal fish due to eutrophication-induced hypoxia in the Kattegat, Sweden. Can J Fish Aquat Sci 51:321-336

Pihl L, Baden SP, Diaz RJ (1991) Effects of periodic hypoxia on 
distribution of demersal fish and crustaceans. Mar Biol 108:349-360

Pihl L, Baden SP, Diaz RJ, Schaffner LC (1992) Hypoxiainduced structural changes in the diet of bottom-feeding fish and crustacea. Mar Biol 112:349-361

Pinckney JL, Millie DF, Vinyard BT, Paerl HW (1997) Environmental controls of phytoplankton bloom dynamics in the Neuse River Estuary, North Carolina, USA. Can J Fish Aquat Sci 54:2491-2501

Powers SP, Harper DE Jr, Rabalais NN (2001) The effect of large scale hypoxia/anoxia on the supply and settlement of benthic invertebrate larvae. In: Rabalais NN, Turner RE (eds) Coastal hypoxia: consequences for living resources. Coastal and Estuarine Studies 58. American Geophysical Union, Washington, DC, p 165-184

Rabalais NN, Wiseman WJ, Turner RE (1994) Comparison of continuous records of near-bottom dissolved oxygen from the hypoxia zone of Louisiana. Estuaries 17:850-861

Rabalais NN, Harper DE Jr, Turner RE (2001a) Responses of nekton and demersal and benthic fauna to decreasing oxygen concentrations. In: Rabalais NN, Turner RE (eds) Coastal hypoxia: consequences for living resources. Coastal and Estuarine Studies 58. American Geophysical Union, Washington, DC, p 115-128

Rabalais NN, Smith LE, Harper DE Jr, Justic D (2001b) Effects of seasonal hypoxia on continental shelf benthos. In: Rabalais NN, Turner RE (eds) Coastal hypoxia: consequences for living resources. Coastal and Estuarine Studies 58. American Geophysical Union, Washington, DC, p 211-240

Richardson K, Heilmann JP (1995) Primary production in the Kattegat: past and present. Ophelia 41:317-328

Robbins J, Bales J (1995) Simulation model of hydrodynamics

Editorial responsibility: Otto Kinne (Editor-in-Chief), Oldendorf/Luhe, Germany and solute transport in the Neuse River Estuary, NC. USGS Open File Report No. 94-511. US Geological Survey, Raleigh, NC

Rosenberg R (1985) Eutrophication-the future marine coastal nuisance? Mar Pollut Bull 16:227-231

Rosenberg R, Loo L (1988) Marine eutrophication induced oxygen deficiency: effects on soft bottom fauna, Western Sweden. Ophelia 29:213-225

Rosenberg R, Loo L, Moller P (1992) Hypoxia, salinity, and temperature as structuring factors for marine benthic communities in a eutrophic area. Neth J Sea Res 30:121-129

Santos SL, Simon JL (1980) Marine soft-bottom community establishment following annual defaunation: larval or adult recruitment? Mar Ecol Prog Ser 2:235-241

Seitz RD, Marshall LS, Hines AH, Clark KL (2003) Effects of hypoxia on predator-prey dynamics of the blue crab Callinectes sapidus and the Baltic clam Macoma balthica in Chesapeake Bay. Mar Ecol Prog Ser 257:179-188

Skilleter GA, Peterson CH (1994) Control of foraging behavior of individuals within an ecosystem context: the clam Macoma balthica and interactions between competition and siphon cropping. Oecologia 100:268-278

Stanley DW, Nixon SW (1992) Stratification and bottom-water hypoxia in the Pamlico River estuary. Estuaries 15: $270-281$

Stow CA, Borsuk ME, Stanley DW (2001) Long-term changes in watershed nutrient inputs and riverine exports in the Neuse River, North Carolina. Water Res 35:1489-1499

Tenore KR (1972) Macrobenthos of the Pamlico River estuary, North Carolina. Ecol Monogr 42:51-69

Warwick RM, Clarke KR (1991) A comparison of some methods for analysing changes in benthic community structure. J Mar Biol Assoc UK 71:225-244

Submitted: August 26, 2004; Accepted: April 28, 2005

Proofs received from author(s): October 19, 2005 